\title{
Role of metallothioneins in benign and malignant thyroid lesions
}

\author{
Bartosz Pula ${ }^{1}$, Pawel Domoslawski ${ }^{2}$, Marzena Podhorska-Okolow ${ }^{1}$ and Piotr Dziegiel ${ }^{1,3^{*}}$
}

\begin{abstract}
Recent findings in the past two decades have brought many insights into the biology of thyroid benign and malignant lesions, in particular the papillary and follicular thyroid cancers. Although, much progress have been made, thyroid cancers still pose diagnostic problems regarding differentiation of follicular lesions in relation to their aggressiveness and the treatment of advanced and undifferentiated thyroid cancers. Metallothioneins (MTs) were shown to induce cancer cells proliferation, mediate resistance to apoptosis, certain chemotherapeutics and radiotherapy. Therefore, MTs may be of utility in diagnosis and management of patients with benign and malignant lesions of the thyroid.
\end{abstract}

Keywords: Metallothionein, Thyroid, Nodular goiter, Cancer

\section{Introduction}

Thyroid cancer is regarded as the most common cancer of the endocrine organs and among all cancers it accounts approximately up to $2.5 \%$ of all malignancies $[1,2]$. Although, the death rates remain relatively low, there is a growing trend towards higher incidence of thyroid cancer which might not be explained by progress in detection of even relatively small thyroid cancers $[1,3,4]$. The majority of cancers of this organ develop from follicular epithelial cells and due to their morphology and biology are divided grossly into two groups. The first group, the well differentiated thyroid cancers, which include the papillary thyroid carcinoma (PTC) and the follicular thyroid carcinoma (FTC) are usually slow growing, characterized by iodine intake and susceptible to TSHsuppressive therapy [5-7]. The PTC accounts for approximately up to $80 \%$ of thyroid tumours, whereas the FTC accounts for $5-15 \%$ of diagnosed thyroid malignancies [8]. These cancers are usually curable utilizing combined surgical and radioiodine therapy in contrast to the anaplastic thyroid cancer (ATC), which represents the poorly differentiated thyroid cancers [7]. ATC comprises only $1-2 \%$ of all diagnosed thyroid malignancies, but is characterized by

\footnotetext{
* Correspondence: piotr.dziegiel@am.wroc.pl

${ }^{1}$ Department of Histology and Embryology, Medical University in Wroclaw,

Wroclaw, Poland

${ }^{3}$ Department of Physiotherapy, Wroclaw University School of Physical

Education in Wroclaw, Wroclaw, Poland

Full list of author information is available at the end of the article
}

rapid and invasive growth resulting in fulminant disease course and poor outcome [7,9]. In thyroid, approximately $5 \%$ of thyroid malignancies are diagnosed as medullary carcinoma, which in turn originates from the parafollicular C cells [7].

All the above mentioned histological variants of thyroid carcinomas may be easily distinguished upon histopathological examination, however in case of FTC problems may occur in distinguishing these tumors from benign follicular adenomas (FA) and follicular variants of PTC (FVPTC) [6]. In case of FTC and FA the differential diagnosis is made by identification of signs of invasiveness into the tumour capsule in numerous serial hematoxyline and eosine stained slides. This renders the fine-needle aspirates (FNA) of thyroid follicular nodules useless for diagnostic purposes and biopsies not allowing for determination of the lesions malignant potential are determined as of indeterminate significance [5]. Up to $40 \%$ of FNA are regarded as indeterminate and subsequently the majority of the patients undergo surgery, but only the minority of the resected thyroid nodules are classified as malignant [10-14]. Moreover, no immunohistochemical markers of invasiveness in FNA have been so far discovered [5,15]. Molecular testing of FNA and resected thyroid specimens may be of value, but none of the recently discovered mutations in thyroid tissue is widely used in the clinical practice $[7,16]$. 
Recent progress in molecular methods resulted in better understanding of the biology of thyroid tumours. It seems that metallothioneins (MTs), due to their characteristic properties may help in the differential diagnosis of thyroid tumours and patients management. This review presents the current knowledge regarding their expression in benign, as well as malignant thyroid lesions.

\section{Metallothionein structure, synthesis and biological functions}

MTs are low molecular weight proteins $(6-7 \mathrm{kDa})$, which are expressed in almost all types of organisms [17-19]. MTs were first isolated in 1957 from horse renal cortex and since then our knowledge concerning these highly conserved proteins have evolved $[18,20]$. All MTs posses a highly conserved amino acid sequence and MTs isolated from different animal species show little structural changes. A single MT molecule consists of 61-68 amino acids, depending on the isoform, where up to one third of proteins sequence is composed of cysteine (Cys) residues $[17,21]$. Interestingly, this residues are organized in typical tandem sequences, with up to two other amino acids occurring between two cysteins [21]. Due to such high cysteine content, MT possess the ability to bind up to seven bivalent metal ions, such as zinc, copper, mercury, lead [19], Moreover, MTs may bind up to twelve univalent metal ions [19,22].

In the overall structure of MTs two domains have been recognized, the domain $\alpha$ and $\beta$ [23]. The domain $\alpha$ comprises amino acids $31-68$ and is located on the $C$ terminal edge, whereas the $\mathrm{N}$-terminal domain $\beta$ comprises amino acids 1-30 [20]. The latter due to its highest antigencity is used for production of antibodies, but due to high homology of particular MT isoforms, the utility of such obtained antibodies in distinguishing particular MT isoforms is therefore highly limited [20,24,25]. Although, MTs form a homogenous group of proteins (according to their amino acid sequence and overall structure leading to charge differences), four principal isoforms could be distinguished: MT-1, MT-2, MT-3 and MT-4 [26]. Most of our knowledge concerning MTs biology stems from research directed on examination of the MT-1 and MT-2 isoforms (MT-1/2), which are ubiquitously expressed in almost all cells of the organism [27]. Expression of MT-3 at first seemed to be more specific and restricted only to neurons and was first isolated from rat brain extracts suffering to experimental Alzheimer disease [28-30]. MT-3 is also known under the synonym growth inhibitory factor (GIF) as it experimentally blocked the regeneration of neurons in injured nervous tissue [30]. Recent studies have brought more insights into the biology of this protein, as it was also found to be expressed in some normal tissues as well as in different tumour types [31-37]. The expression of MT-4 seems to be restricted only to squamous epithelium of the skin and upper parts of the alimentary tract [38].

MTs are encoded by 17 genes located within the $16 q 13$ region, from which 13 code for MT-1, two for MT-2 and one gene each coding for MT-3 and MT-4 $[26,38,39]$. However, at least 10 genes code for functional MT proteins: MT-1A, MT-1B, MT-1E, MT-1F, MT-1G, MT-1H, MT-1X, MT-2A, MT-3 and MT-4 [24,26]. Beside the functional isoforms, there were also seven non-functional isoforms identified: MT-1C, MT-1D, MT-1I, MT-1J, MT-1K, MT-1L and MT-2B [26,40]. MTs were found to be localized in cells cytoplasm, as well as in cell nucleus $[20,41]$. Isoforms of the MT-1 and MT-2 family were shown to be induced by several substances and agents e.g. heavy metals, steroids, cytokines, growth factors and free radicals [42-46]. Zinc ion seems to represent the natural biological compound responsible for the induction of MTs expression. Zinc ions bind to the metal response element-binding transcription factor (MTF-1), which interacts via its zinc finger domains with a particular DNA region - the so called metal response element (MRE). Binding of MTF-1 to MRE results in initiation of MT-1/2 gene transcription [47-49]. Metal ions, other than zinc, induce MT-1/2 expression independently of the binding to the MTF-1 transcription factor as they may not activate this protein. However, these metal ions possess higher affinity to MT- $1 / 2$ proteins as compared to zinc ions, what results with the release of the latter to the cytoplasm. As result, free zinc ions bind to the MTF-1, what activates the transcription of MT-1/2 genes [50-52]. Similar mechanism is observed during oxidative stress, in which MTs oxidation by hydrogen peroxide $\left(\mathrm{H}_{2} \mathrm{O}_{2}\right)$ leads to release of zinc ions from these proteins $[53,54]$. Regulation of MTs expression by glucocorticoid hormones is regulated independently of the above mentioned mechanism, as glucocorticoid receptors bind to the specific regulatory sequence (GRE; glucocorticoid response element) in the promoter region of MTs genes activating their transcription [27,55]. MTs expression may be also induced during stress conditions via the antioxidant response element (ARE) [17,56,57].

Although, MT-3 shows approximately 70\% sequence similarity to other MTs, however there are some differences in its structure, what might reflect its functional diversity in comparison to other MTs. MT-3 posses a glutamate-rich hexapeptide near the $\mathrm{C}$-terminus and contains a CPCP (Cys-Pro-Cys-Pro) motif (amino acids 6-9), which is absent in other MTs [29,58]. This might be reflected by the unique growth inhibitory role of MT-3, not apparent in other MTs [28-30,58].

\section{Metallothioneins in neoplasia}

Lines of evidence point to significant role of MTs of the MT-1 and MT-2 isoforms in development and progression 
of numerous neoplastic diseases $[18,41,59,60]$. Due to the metal binding properties of MTs, these proteins may act as possible zinc ions donors for zinc-dependent enzymes and transcription factors, which play crucial role in processes such as replication, transcription and translation $[18,61]$. It was shown, that in inactive cells (G0 phase) MTs can be detected in the cytoplasm, whereas in cells undergoing division MTs are shifted to the nucleus. In addition, the high cytoplasmic expression of MTs is noted at the end of G1 phase and at the G1/S threshold, while the highest MTs concentration in cell nucleus was noted in the S and G2 phases $[62,63]$. The translocation of MTs into the nucleus during G1/S phase in tumour cells suggests that MTs facilitates cell proliferation by donating zinc ions to various transcription factors. Moreover, numerous reports based on immunohistochemical methods seemed to confirm the results obtained in vitro suggesting the role o MTs in cell cycle regulation, as MTs expression was detected in the cell cytoplasm and nucleus in organs undergoing growth or regeneration (e.g. liver, kidney and parabasal cells of stratified epithelium) [64-67]. In addition, MTs overexpression is frequently observed in various malignancies (epithelial as well as mesenchymal tumours) and in some cases increased with growing malignancy grade of those tumours [20,24,66-75]. Lines of evidence suggest, that MTs may diminish the suppressor function of the p53 protein leading to uncontrolled growth and proliferation $[61,76]$. Numerous experimental data have, shown a positive correlation of MT expression and Ki-67 or PCNA (proliferating cell nuclear antigen) antigens in human tumour tissues, supporting the pro-proliferative role of MTs [24,25,59,68,69,77,78].

Higher expression of MTs in human tumours was also linked to increased chemoresistance of some tumour types (e.g. gastric, ovarian, breast cancer), as it levels increased after chemotherapy with agents such as cisplatin, bleomycin, irinotecan or cyclophosphamide [41,79-81]. Due to the structure of MTs, they may diminish the effects of agents inducing the oxidative stress (daunorubicin, doxorubicin), in mechanism involving inactivation of free radicals $[20,82]$. Thanks to the high affinity of MTs to metal ions, these proteins may also inactivate alkylating drugs, characterized by cytotoxic effects dependent on heavy metal compounds (e.g. cisplatin, carboplatin) [83]. Several studies have shown that MTs may mediate cancer cells chemoresistance in human malignant tumours characterized by MTs overexpression [79,81,84-86]. Moreover, free radicals scavenging properties MTs may also take part in cancer cells resistance to radiotherapy [87].

Most of the studies have revealed, that MT- $1 / 2$ overexpression in malignant cells is associated with poor survival of patients with e.g. non-small cell lung cancer, intrahepatic cholangiocarcionoma, synovial sarcoma, renal cancer or melanoma $[24,70,71,88-90]$. However, some of the studies have showed that MTs in some tumour types do not yield any prognostic significance, or - in some case - were even associated with patients better prognosis [72,91]. Interestingly, in some studies MT-1G (hepatocellular and papillary thyroid cancer), MT-1F (colorectal cancer) and MT-3 (gastric and esophageal cancer) isoform were regarded as potent tumour suppressors [92-97]. In spite of many efforts, the role of MT-3 in neoplastic disease remains ambiguous and the results of the studies were frequently inconsistent $[31,32,36,37,98,99]$. Therefore it seems, that the role of particular metallothionein isoforms differ significantly and the utilization of MTs as potent prognostic factors in human cancers requires further research.

\section{Metallothionein expression in thyroid tissues}

First study regarding MTs expression in human thyroid tissue was performed by Nartney et al. in 1987, who used a polyclonal rabbit anti-MT antibody to examine the expression levels of MTs in surgically resected tumour samples and normal thyroid tissue biopsied from autopsy cases [100]. This pilot study revealed that in paraffin embedded tissues of normal thyroid, only $20 \%$ of analyzed cases expressed MTs in the nucleus of follicular thyroid cells, whereas a nuclear-cytoplasmic expression pattern of MT was noted in majority of the surgically resected tumour samples (91\%) [100]. The results obtained by Nartney et al. regarding MTs expression in normal thyroid tissues were not in accordance with the results obtained by other studies, which showed that MTs expression is mostly downregulated in thyroid cancers when compared to normal thyroid follicular cells or benign lesions of the thyroid e.g. nodular goiter (Figure 1) [15,92,101,102]. These studies were performed either on paraffin-embedded tissues using immunohistochemistry or on fresh frozen material utilizing expression microarrays or real-time PCR. The latter allowed to distinguish the expression of particular functional MTs isoforms - data not possible to obtain with currently available antibodies due to the homogenous structure of MTs isoforms [92,101,102].

The microarray studies identified MT-1G gene expression as downregulated in PTC and FTC, supporting recent reports of MT-1G suppressor role in human colon and hepatocellular carcinoma [91-93,101,102]. Lines of evidence suggest that hypermethylation of gene promoters occurs frequently in thyroid cancers and may be responsible for altered expression of sodium-iodide symporter (NIS), proteins associated with adhesion or cell cycle [103-105]. Moreover, treatment of thyroid cancer cell lines with demethylating agents could restore the dedifferentiation of thyroid cancer cell lines and their ability to iodide uptake [105]. The decreased expression of 

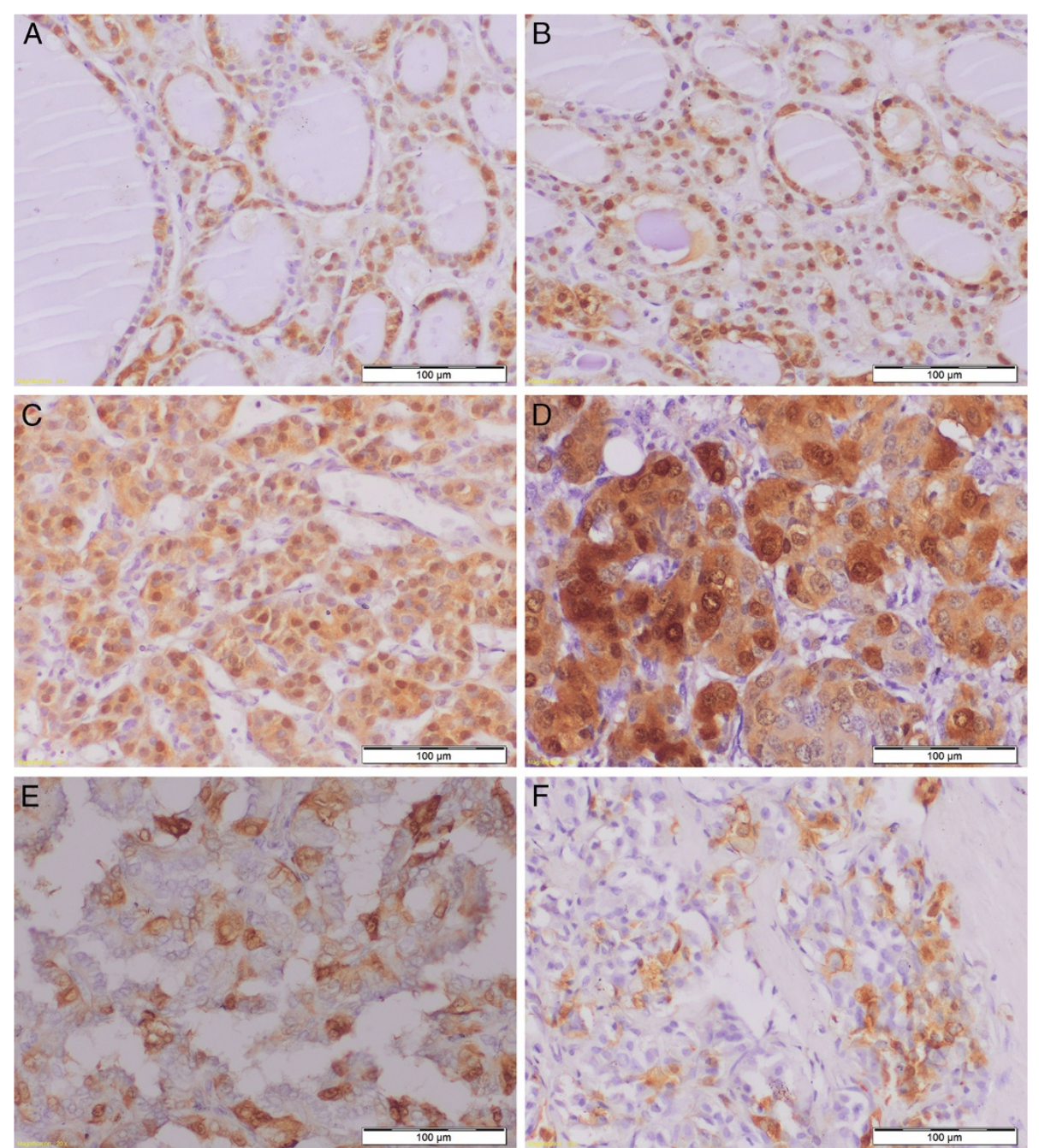

Figure 1 Differentiated nyclear cytoplasmic MT-1/2 expression in normal thyroid cells (A), nodular goiter (B), follicular adenoma (C), follicular carcinoma (D), papillary carcinoma (E) and medullary carcinoma (F). Magnification $\times 200$.

MT-1G in PTC was caused by the hypermethylation of the $\mathrm{CpG}$ islands, but not the loss of heterozygosity ( $\mathrm{LOH})$ [103]. This observations were also confirmed on cell lines derived from human PTCs: NPA-87 (poorly differentiated), K1 and K2 (well-differentiated) [103,106,107]. The treatment of $\mathrm{K} 2$ cell line, which showed the highest level of methylation, with demethylating agent 5-aza2'-deoxycytidene and/or trichostatin A (a histone deacetylase inhibitor) induced the higher expression level of MT-1G [103]. Similar results were described with the $\mathrm{K} 1$ cell line [92].

Beside the MT-1G, also MT- $1 \mathrm{H}$ and MT-1X were shown to be downregulated in human PTC and FTC [92]. Also in the study of Finn et al., it was demonstrated that in PTCs with classic morphology, as well as in the FVPTCs, MTs expression was downregulated what points to a potential application of MTs as markers of thyroid malignancy [101]. Nevertheless, also in this aspect the biological significance of the above mentioned findings requires further research.

\section{Biological significance of MTs expression in thyroid cancers}

The biological importance of MTs expression was only assessed in relation to the MT-1G isoform in the study of Ferrario et al., in which the expression of this isoform was restored in the $\mathrm{K} 1$ thyroid papillary cancer cell line with use of a MT-1G-myc expression plasmid [92]. MT-1G introduction into the K1 cell line resulted in reduced growth rate in respect to control cells subsequently leading to formation of smaller colonies. The suppressory role of MT-1G was additionally confirmed in vivo in athymic nude mice, as $\mathrm{K} 1$ cells with MT-1G expression yielded reduced tumour growth as compared to control cells [92]. Downregulation of MTs in PTC may be also partly responsible for decreased 
inactivation of reactive oxygen species observed in this tumour type, what might contribute to the carcinogenesis process $[108,109]$.

Impact of MTs expression on carcinogenesis of thyroid cancer was also analysed in both studies of Liu et al. with regard to papillary (KAT5 cells) and anaplastic thyroid cancer (ARO cell line) $[110,111]$. In both studies the cell lines were subjected to treatment with cadmium ions (a potent inductor of MTs expression), in order to examine the impact of MTs isoforms on carcinogenesis. Cadmium treatment led to the induction of MT-1 and MT-2 isoforms in both cell lines, although differences in MT profile were observed [110,111]. In the KAT5 cells, the MT-1G and MT-2A levels were identified as being the most abundant isoforms upon cadmium treatment, whereas in the ARO cell line additionally the MT-1A, MT-1F, MT-1H, MT-1X were identified as the main functional isoforms $[110,111]$. Both studies have shown that induction of those isoforms was accompanied by alteration in the cell cycle leading to increase of proportion of cells in the $\mathrm{S}$ and G2-M phase and decrease in the proportion of cells in the G0/G1 phase [110,111]. Moreover, cadmium treatment resulted also in rise of calcium ions influx and led to a moderate rise in the phoshorylated ERK1/2 (extracellular signal-regulated kinase), both processes capable of stimulating cells proliferation [112]. Although, it was shown that the expression of MT-1G may alter proliferative response of KAT5 cells, the results of both studies should be taken with caution, because the study design did not allow clear assessment of MTs role in the observed cell cycle alterations [92,110,111]. Moreover, in our own study we did not observe any significant correlation between the expression of the MT-1/2 and the proliferation antigen $\mathrm{Ki}-67$ in the series of PTC and FTC cases [15].

\section{Clinical significance of MTs in thyroid}

Although, the prognostic significance of MTs expression in thyroid cancer remains to be clarified, some of the obtained results may have potential to be to applied in clinical practice. Recent advance in molecular testing of thyroid carcinomas led to the identification of genes altered in particular type of the thyroid cancer $[3,5,9,16]$. It has become apparent that PTC and FTC harbour different mutations. PTC is characterized by the mutations in the RAS and BRAF genes as well as by rearrangements of the RET/PTC genes capable of activating the mitogen activated kinase (MAPK) pathway. In FTC alterations in the RAS gene and PAX8/PPAR $\gamma$ rearrangements were identified in majority of the cases [16]. However, these mutations were also shown to occur in benign thyroid lesions. This fact, on one hand confirms the multistep carcinogenesis process in the thyroid, but on the other may render difficulties in introducing these new findings into clinical practice [7]. MTs expression shown as downregulated in majority of the thyroid cancer studies, could be used as an ancillary marker helping in differential diagnosis of indeterminate FNA or surgical specimens of thyroid lesions [15,92,101-103]. We have recently shown that immunohistochemical examination of MT-1/2 expression may be of use in differentiating FA from FTC, which are impossible to distinguish in FNA examination $[6,8]$. The higher expression of MT-1/2 observed in FTC as compared to FA may be of clinical importance, although this finding must be confirmed on a larger patients cohort with establishing proper cut-off points for the diagnosis [15]. Moreover, the pronounced expression of MT-1/2 in FTC may be linked to resistance to radiotherapy.

\section{Conclusions}

MTs due to their wide functional properties, potentially associated with progression of majority of human cancers may pose an interesting point of research in relation to human malignant thyroid lesions.

\section{Competing interests}

The authors declare that no competing financial interests exist.

\section{Authors' contributions}

All the authors drafted the manuscript. All the authors read and approved the final manuscript.

\section{Acknowledgements}

This work was supported by the scientific grant of Wroclaw Medical University, No. ST-442.

\section{Author details}

'Department of Histology and Embryology, Medical University in Wroclaw, Wroclaw, Poland. ²Department of General, Gastroenterological and Endocrinological Surgery, Medical University in Wroclaw, Wroclaw, Poland. ${ }^{3}$ Department of Physiotherapy, Wroclaw University School of Physical Education in Wroclaw, Wroclaw, Poland.

Received: 17 December 2012 Accepted: 18 December 2012 Published: 28 December 2012

\section{References}

1. Patel KN, Shaha AR: Poorly differentiated and anaplastic thyroid cancer. Cancer Control 2006, 13:119-128.

2. Siegel $R$, Naishadham D, Jemal A: Cancer statistics, 2012. CA Cancer J Clin 2012, 62:10-29.

3. Smallridge RC, Marlow LA, Copland JA: Anaplastic thyroid cancer: molecular pathogenesis and emerging therapies. Endocr Relat Cancer 2009, 16:17-44.

4. Davies L, Welch HG: Increasing incidence of thyroid cancer in the United States, 1973-2002. JAMA 2006, 295:2164-2167.

5. LiVolsi VA: Papillary thyroid carcinoma: an update. Mod Pathol 2011, 24(Suppl 2):S1-9.

6. Sobrinho-Simoes M, Eloy C, Magalhaes J, Lobo C, Amaro T: Follicular thyroid carcinoma. Mod Pathol 2011, 24(Suppl 2):S10-18.

7. Catalano MG, Poli R, Pugliese M, Fortunati N, Boccuzzi G: Emerging molecular therapies of advanced thyroid cancer. Mol Aspects Med 2010, 31:215-226.

8. Mazzaferri EL: Thyroid cancer in thyroid nodules: finding a needle in the haystack. Am J Med 1992, 93:359-362.

9. Smallridge RC, Copland JA: Anaplastic thyroid carcinoma: pathogenesis and emerging therapies. Clin Oncol (R Coll Radiol) 2010, 22:486-497.

10. Cooper DS, Doherty GM, Haugen BR, Kloos RT, Lee SL, Mandel SJ, Mazzaferri EL, Mclver B, Pacini F, Schlumberger M, Sherman SI, Steward DL, Tuttle RM: 
Revised American Thyroid Association management guidelines for patients with thyroid nodules and differentiated thyroid cancer. Thyroid 2009, 19:1167-1214

11. Cooper DS, Doherty GM, Haugen BR, Kloos RT, Lee SL, Mandel SJ, Mazzaferri EL, Mclver B, Sherman SI, Tuttle RM: Management guidelines for patients with thyroid nodules and differentiated thyroid cancer. Thyroid 2006, 16:109-142.

12. Sclabas GM, Staerkel GA, Shapiro SE, Fornage BD, Sherman SI, Vassillopoulou-Sellin R, Lee JE, Evans DB: Fine-needle aspiration of the thyroid and correlation with histopathology in a contemporary series of 240 patients. Am J Surg 2003, 186:702-709. discussion 709-710.

13. Greaves TS, Olvera M, Florentine BD, Raza AS, Cobb CJ, Tsao-Wei DD, Groshen S, Singer P, Lopresti J, Martin SE: Follicular lesions of thyroid: a 5-year fine-needle aspiration experience. Cancer 2000, 90:335-341.

14. Alexander EK, Kennedy GC, Baloch ZW, Cibas ES, Chudova D, Diggans J, Friedman L, Kloos RT, LiVolsi VA, Mandel SJ, Raab SS, Rosai J, Steward DL, Walsh PS, Wilde Jl, Zeiger MA, Lanman RB, Haugen BR: Preoperative diagnosis of benign thyroid nodules with indeterminate cytology. N Engl J Med 2012, 367:705-715.

15. Krolicka A, Kobierzycki C, Pula B, Podhorska-Okolow M, Piotrowska A Rzeszutko M, Rzeszutko W, Rabczynski J, Domoslawski P, Wojtczak B, Dawiskiba J, Dziegiel P: Comparison of metallothionein (MT) and Ki-67 antigen expression in benign and malignant thyroid tumours. Anticancer Res 2010, 30:4945-4949.

16. Nikiforov YE: Molecular analysis of thyroid tumors. Mod Pathol 2011, 24(Suppl 2):S34-43.

17. Vasak M, Meloni G: Chemistry and biology of mammalian metallothioneins. J Biol Inorg Chem 2011, 16:1067-1078.

18. Pedersen MO, Larsen A, Stoltenberg M, Penkowa M: The role of metallothionein in oncogenesis and cancer prognosis. Prog Histochem Cytochem 2009, 44:29-64.

19. Coyle P, Philcox JC, Carey LC, Rofe AM: Metallothionein: the multipurpose protein. Cell Mol Life Sci 2002, 59:627-647.

20. Dziegiel P: Expression of metallothioneins in tumor cells. Pol J Pathol 2004, 55:3-12

21. Vasak M: Advances in metallothionein structure and functions. J Trace Elem Med Biol 2005, 19:13-17.

22. Palmiter RD: The elusive function of metallothioneins. Proc Natl Acad Sci USA 1998, 95:8428-8430.

23. Zangger K, Shen G, Oz G, Otvos JD, Armitage IM: Oxidative dimerization in metallothionein is a result of intermolecular disulphide bonds between cysteines in the alpha-domain. Biochem J 2001, 359:353-360.

24. Werynska B, Pula B, Muszczynska-Bernhard B, Gomulkiewicz A, Piotrowska A, Prus R, Podhorska-Okolow M, Jankowska R, Dziegiel P: Metallothionein $1 \mathrm{~F}$ and $2 \mathrm{~A}$ overexpression predicts poor outcome of non-small cell lung cancer patients. Exp Mol Pathol 2012, doi:pii: S0014-4800(12)00153-0. 10.1016/j.yexmp.2012.10.006. [Epub ahead of print].

25. Werynska B, Pula B, Muszczynska-Bernhard B, Piotrowska A, Jethon A, Podhorska-Okolow M, Dziegiel P, Jankowska R: Correlation between expression of metallothionein and expression of Ki-67 and MCM-2 proliferation markers in non-small cell lung cancer. Anticancer Res 2011, 31:2833-2839.

26. Mididoddi S, McGuirt JP, Sens MA, Todd JH, Sens DA: Isoform-specific expression of metallothionein mRNA in the developing and adult human kidney. Toxicol Lett 1996, 85:17-27.

27. Davis SR, Cousins RJ: Metallothionein expression in animals: a physiological perspective on function. J Nutr 2000, 130:1085-1088.

28. Uchida Y: Growth-inhibitory factor, metallothionein-like protein, and neurodegenerative diseases. Biol Signals 1994, 3:211-215.

29. Uchida Y, Takio K, Titani K, Ihara Y, Tomonaga M: The growth inhibitory factor that is deficient in the Alzheimer's disease brain is a 68 amino acid metallothionein-like protein. Neuron 1991, 7:337-347.

30. Uchida Y, Tomonaga M: Neurotrophic action of Alzheimer's disease brain extract is due to the loss of inhibitory factors for survival and neurite formation of cerebral cortical neurons. Brain Res 1989, 481:190-193.

31. Garrett SH, Park S, Sens MA, Somij S, Singh RK, Namburi VB, Sens DA: Expression of metallothoinein isoform 3 is restricted at the post-transcriptional level in human bladder epithelial cells. Toxicol Sci 2005, 87:66-74.

32. Garrett SH, Sens MA, Shukla D, Nestor S, Somji S, Todd JH, Sens DA: Metallothionein isoform 3 expression in the human prostate and cancerderived cell lines. Prostate 1999, 41:196-202.
33. Garrett SH, Sens MA, Todd JH, Somji S, Sens DA: Expression of MT-3 protein in the human kidney. Toxicol Lett 1999, 105:207-214.

34. Hoey JG, Garrett SH, Sens MA, Todd JH, Sens DA: Expression of MT-3 mRNA in human kidney, proximal tubule cell cultures, and renal cell carcinoma. Toxicol Lett 1997, 92:149-160.

35. Kim D, Garrett SH, Sens MA, Somji S, Sens DA: Metallothionein isoform 3 and proximal tubule vectorial active transport. Kidney Int 2002, 61:464-472.

36. Sens MA, Somji S, Garrett SH, Beall CL, Sens DA: Metallothionein isoform 3 overexpression is associated with breast cancers having a poor prognosis. Am J Pathol 2001, 159:21-26.

37. Sens MA, Somji S, Lamm DL, Garrett SH, Slovinsky F, Todd JH, Sens DA: Metallothionein isoform 3 as a potential biomarker for human bladder cancer. Environ Health Perspect 2000, 108:413-418.

38. Quaife CJ, Findley SD, Erickson JC, Froelick GJ, Kelly EJ, Zambrowicz BP, Palmiter RD: Induction of a new metallothionein isoform (MT-IV) occurs during differentiation of stratified squamous epithelia. Biochemistry 1994 33:7250-7259

39. Palmiter RD, Findley SD, Whitmore TE, Durnam DM: MT-III, a brain-specific member of the metallothionein gene family. Proc Natl Acad Sci USA 1992 89:6333-6337.

40. Stennard FA, Holloway AF, Hamilton J, West AK: Characterisation of six additional human metallothionein genes. Biochim Biophys Acta 1994, 1218:357-365.

41. Cherian MG, Jayasurya A, Bay BH: Metallothioneins in human tumors and potential roles in carcinogenesis. Mutat Res 2003, 533:201-209.

42. Haq F, Mahoney M, Koropatnick J: Signaling events for metallothionein induction. Mutat Res 2003, 533:211-226.

43. Ghoshal K, Jacob ST: Regulation of metallothionein gene expression. Prog Nucleic Acid Res Mol Biol 2001, 66:357-384.

44. Ghoshal K, Majumder S, Li Z, Bray TM, Jacob ST: Transcriptional induction of metallothionein-I and - II genes in the livers of $\mathrm{Cu}, \mathrm{Zn}$-superoxide dismutase knockout mice. Biochem Biophys Res Commun 1999, 264:735-742

45. Ghoshal K, Wang Y, Sheridan JF, Jacob ST: Metallothionein induction in response to restraint stress. Transcriptional control, adaptation to stress, and role of glucocorticoid. J Biol Chem 1998, 273:27904-27910.

46. Jacob ST, Ghoshal K, Sheridan JF: Induction of metallothionein by stress and its molecular mechanisms. Gene Expr 1999, 7:301-310.

47. Saydam N, Adams TK, Steiner F, Schaffner W, Freedman JH: Regulation of metallothionein transcription by the metal-responsive transcription factor MTF-1: identification of signal transduction cascades that control metal-inducible transcription. J Biol Chem 2002, 277:20438-20445.

48. Otsuka F, Okugaito I, Ohsawa M, Iwamatsu A, Suzuki K, Koizumi S: Novel responses of ZRF, a variant of human MTF-1, to in vivo treatment with heavy metals. Biochim Biophys Acta 2000, 1492:330-340.

49. Langmade SJ, Ravindra R, Daniels PJ, Andrews GK: The transcription factor MTF-1 mediates metal regulation of the mouse $\mathrm{ZnT1}$ gene. J Biol Chem 2000, 275:34803-34809.

50. Murata M, Gong P, Suzuki K, Koizumi S: Differential metal response and regulation of human heavy metal-inducible genes. J Cell Physiol 1999, 180:105-113.

51. Koizumi S, Suzuki K, Ogra Y, Yamada H, Otsuka F: Transcriptional activity and regulatory protein binding of metal-responsive elements of the human metallothionein-IIA gene. Eur J Biochem 1999, 259:635-642.

52. Lichtlen P, Schaffner W: The "metal transcription factor" MTF-1: biological facts and medical implications. Swiss Med Wkly 2001, 131:647-652.

53. Nguyen T, Sherratt PJ, Pickett CB: Regulatory mechanisms controlling gene expression mediated by the antioxidant response element. Annu Rev Pharmacol Toxicol 2003, 43:233-260.

54. Andrews GK: Regulation of metallothionein gene expression by oxidative stress and metal ions. Biochem Pharmacol 2000, 59:95-104.

55. Hernandez J, Carrasco J, Belloso E, Giralt M, Bluethmann H, Kee Lee D, Andrews GK, Hidalgo J: Metallothionein induction by restraint stress: role of glucocorticoids and IL-6. Cytokine 2000, 12:791-796

56. Bi Y, Palmiter RD, Wood KM, Ma Q: Induction of metallothionein I by phenolic antioxidants requires metal-activated transcription factor 1 (MTF-1) and zinc. Biochem J 2004, 380:695-703.

57. Campagne MV, Thibodeaux H, van Bruggen N, Cairns B, Lowe DG Increased binding activity at an antioxidant-responsive element in the metallothionein-1 promoter and rapid induction of metallothionein-1 
and -2 in response to cerebral ischemia and reperfusion. J Neurosci 2000, 20:5200-5207.

58. Ding ZC, Ni FY, Huang ZX: Neuronal growth-inhibitory factor (metallothionein-3): structure-function relationships. FEBS J 2010, 277:2912-2920.

59. Dziegiel P, Dumanska M, Forgacz J, Wojna A, Zabel M: Intensity of apoptosis as related to the expression of metallothionein (MT), caspase-3 (cas-3) and Ki-67 antigen and the survival time of patients with primary colorectal adenocarcinomas. Rocz Akad Med Bialymst 2004, 49(Suppl 1):5-7.

60. Nielsen $A E$, Bohr A, Penkowa M: The balance between life and death of cells: roles of metallothioneins. Biomark Insights 2007, 1:99-111.

61. Ostrakhovitch EA, Olsson PE, von Hofsten J, Cherian MG: P53 mediated regulation of metallothionein transcription in breast cancer cells. J Cell Biochem 2007, 102:1571-1583.

62. Cherian MG, Apostolova MD: Nuclear localization of metallothionein during cell proliferation and differentiation. Cell Mol Biol (Noisy-le-Grand) 2000, 46:347-356.

63. Levadoux-Martin M, Hesketh JE, Beattie JH, Wallace HM: Influence of metallothionein-1 localization on its function. Biochem J 2001, 355:473-479.

64. Zalups RK, Fraser J, Koropatnick J: Enhanced transcription of metallothionein genes in rat kidney: effect of uninephrectomy and compensatory renal growth. Am J Physiol 1995, 268:F643-650.

65. Cherian MG, Kang YJ: Metallothionein and liver cell regeneration. Exp Bio Med (Maywood) 2006, 231:138-144.

66. Zamirska A, Matusiak L, Dziegiel P, Szybejko-Machaj G, Szepietowski JC: Expression of metallothioneins in cutaneous squamous cell carcinoma and actinic keratosis. Pathol Oncol Res 2012, 18:849-855.

67. Bieniek A, Pula B, Piotrowska A, Podhorska-Okolow M, Salwa A, Koziol M, Dziegiel P: Expression of metallothionein I/II and Ki-67 antigen in various histological types of basal cell carcinoma. Folia Histochem Cytobiol 2012, 50:352-357.

68. Gomulkiewicz A, Podhorska-Okolow M, Szulc R, Smorag Z, Wojnar A, Zabel $M$, Dziegiel P: Correlation between metallothionein (MT) expression and selected prognostic factors in ductal breast cancers. Folia Histochem Cytobiol 2010, 48:242-248.

69. Wojnar A, Pula B, Piotrowska A, Jethon A, Kujawa K, Kobierzycki C, Rys J, Podhorska-Okolow M, Dziegiel P: Correlation of intensity of MT-I/II expression with $\mathrm{Ki}-67$ and MCM-2 proteins in invasive ductal breast carcinoma. Anticancer Res 2011, 31:3027-3033.

70. Dziegiel P, Jelen M, Muszczynska B, Maciejczyk A, Szulc A, PodhorskaOkolow M, Cegielski M, Zabel M: Role of metallothionein expression in non-small cell lung carcinomas. Rocz Akad Med Bialymst 2004, 49(Suppl 1):43-45.

71. Dziegiel P, Suder E, Surowiak P, Kornafel J, Zabel M: Expression of metallothionein in synovial sarcoma cells. Appl Immunohistochem Mol Morphol 2002, 10:357-362.

72. Pastuszewski W, Dziegiel P, Krecicki T, Podhorska-Okolow M, Ciesielska U, Gorzynska E, Zabel M: Prognostic significance of metallothionein, p53 protein and Ki-67 antigen expression in laryngeal cancer. Anticancer Res 2007, 27:335-342.

73. Surowiak P, Matkowski R, Materna V, Gyorffy B, Wojnar A, Pudelko M Dziegiel P, Kornafel J, Zabel M: Elevated metallothionein (MT) expression in invasive ductal breast cancers predicts tamoxifen resistance. Histol Histopathol 2005, 20:1037-1044.

74. Szelachowska J, Dziegiel P, Jelen-Krzeszewska J, Jelen M, Tarkowski R, Spytkowska B, Matkowski R, Kornafel J: Correlation of metallothionein expression with clinical progression of cancer in the oral cavity. Anticancer Res 2009, 29:589-595.

75. Szelachowska J, Dziegiel P, Jelen-Krzeszewska J, Jelen M, Tarkowski R, Wlodarska I, Spytkowska B, Gisterek I, Matkowski R, Kornafel J: Prognostic significance of nuclear and cytoplasmic expression of metallothioneins as related to proliferative activity in squamous cell carcinomas of oral cavity. Histol Histopathol 2008, 23:843-851.

76. Fan LZ, Cherian MG: Potential role of p53 on metallothionein induction in human epithelial breast cancer cells. Br J Cancer 2002, 87:1019-1026.

77. Hengstler JG, Pilch H, Schmidt M, Dahlenburg H, Sagemuller J, Schiffer I Oesch F, Knapstein PG, Kaina B, Tanner B: Metallothionein expression in ovarian cancer in relation to histopathological parameters and molecular markers of prognosis. Int J Cancer 2001, 95:121-127.

78. Dziegiel P, Salwa-Zurawska W, Zurawski J, Wojnar A, Zabel M: Prognostic significance of augmented metallothionein (MT) expression correlated with Ki-67 antigen expression in selected soft tissue sarcomas. Histol Histopathol 2005, 20:83-89.

79. Chun JH, Kim HK, Kim E, Kim IH, Kim JH, Chang HJ, Choi IJ, Lim HS, Kim IJ, Kang HC, Park JH, Bae JM, Park JG: Increased expression of metallothionein is associated with irinotecan resistance in gastric cancer. Cancer Res 2004, 64:4703-4706.

80. Dutta R, Sens DA, Somji S, Sens MA, Garrett SH: Metallothionein isoform 3 expression inhibits cell growth and increases drug resistance of PC-3 prostate cancer cells. Prostate 2002, 52:89-97.

81. Surowiak P, Materna V, Maciejczyk A, Pudelko M, Markwitz E, Spaczynski M, Dietel M, Zabel M, Lage H: Nuclear metallothionein expression correlates with cisplatin resistance of ovarian cancer cells and poor clinical outcome. Virchows Arch 2007, 450:279-285.

82. Cai L, Cherian MG: Zinc-metallothionein protects from DNA damage induced by radiation better than glutathione and copper- or cadmiummetallothioneins. Toxicol Lett 2003, 136:193-198.

83. Shimoda R, Achanzar WE, Qu W, Nagamine T, Takagi H, Mori M, Waalkes MP: Metallothionein is a potential negative regulator of apoptosis. Toxicol Sci 2003, 73:294-300.

84. Surowiak P, Materna V, Kaplenko I, Spaczynski M, Dietel M, Lage H, Zabel M: Augmented expression of metallothionein and glutathione S-transferase pi as unfavourable prognostic factors in cisplatin-treated ovarian cancer patients. Virchows Arch 2005, 447:626-633.

85. Yap X, Tan HY, Huang J, Lai Y, Yip GW, Tan PH, Bay BH: Over-expression of metallothionein predicts chemoresistance in breast cancer. J Pathol 2009, 217:563-570.

86. Smith DJ, Jaggi M, Zhang W, Galich A, Du C, Sterrett SP, Smith LM, Balaji KC: Metallothioneins and resistance to cisplatin and radiation in prostate cancer. Urology 2006, 67:1341-1347

87. Cai L, Satoh M, Tohyama C, Cherian MG: Metallothionein in radiation exposure: its induction and protective role. Toxicology 1999, 132:85-98.

88. Schmitz KJ, Lang H, Kaiser G, Wohlschlaeger J, Sotiropoulos GC, Baba HA Jasani B, Schmid KW: Metallothionein overexpression and its prognostic relevance in intrahepatic cholangiocarcinoma and extrahepatic hilar cholangiocarcinoma (Klatskin tumors). Hum Pathol 2009, 40:1706-1714.

89. Weinlich G, Zelger B: Metallothionein overexpression, a highly significant prognostic factor in thin melanoma. Histopathology 2007, 51:280-283.

90. Tuzel E, Kirkali Z, Yorukoglu K, Mungan MU, Sade M: Metallothionein expression in renal cell carcinoma: subcellular localization and prognostic significance. J Urol 2001, 165:1710-1713.

91. Arriaga JM, Levy EM, Bravo Al, Bayo SM, Amat M, Aris M, Hannois A, Bruno L, Roberti MP, Loria FS, Pairola A, Huertas E, Mordoh J, Bianchini M: Metallothionein expression in colorectal cancer: relevance of different isoforms for tumor progression and patient survival. Hum Pathol 2012, 43:197-208.

92. Ferrario C, Lavagni P, Gariboldi M, Miranda C, Losa M, Cleris L, Formelli F, Pilotti S, Pierotti MA, Greco A: Metallothionein $1 G$ acts as an oncosupressor in papillary thyroid carcinoma. Lab Invest 2008, 88:474-481.

93. Kanda M, Nomoto S, Okamura Y, Nishikawa Y, Sugimoto H, Kanazumi N, Takeda S, Nakao A: Detection of metallothionein $1 \mathrm{G}$ as a methylated tumor suppressor gene in human hepatocellular carcinoma using a novel method of double combination array analysis. Int J Oncol 2009, 35:477-483.

94. Smith E, Drew PA, Tian ZQ, De Young NJ, Liu JF, Mayne GC, Ruszkiewicz AR, Watson DI, Jamieson GG: Metallothionien 3 expression is frequently down-regulated in oesophageal squamous cell carcinoma by DNA methylation. Mol Cancer 2005, 4:42.

95. Deng D, El-Rifai W, Ji J, Zhu B, Trampont P, Li J, Smith MF, Powel SM: Hypermethylation of metallothionein-3 CpG island in gastric carcinoma. Carcinogenesis 2003, 24:25-29.

96. Yan DW, Fan JW, Yu ZH, Li MX, Wen YG, Li DW, Zhou CZ, Wang XL, Wang $\mathrm{Q}$, Tang HM, Peng ZH: Downregulation of metallothionein $1 \mathrm{~F}$, a putative oncosuppressor, by loss of heterozygosity in colon cancer tissue. Biochim Biophys Acta 2012, 1822:918-926.

97. Peng D, Hu TL, Jiang A, Washington MK, Moskaluk CA, Schneider-Stock R, El-Rifai W: Location-specific epigenetic regulation of the metallothionein 3 gene in esophageal adenocarcinomas. PLoS One 2011, 6:e22009.

98. Gurel V, Sens DA, Somji S, Garrett SH, Nath J, Sens MA: Stable transfection and overexpression of metallothionein isoform 3 inhibits the growth of MCF-7 and Hs578T cells but not that of T-47D or MDA-MB-231 cells. Breast Cancer Res Treat 2003, 80:181-191. 
99. Somji S, Garrett SH, Sens MA, Gurel V, Sens DA: Expression of metallothionein isoform 3 (MT-3) determines the choice between apoptotic or necrotic cell death in $\mathrm{Cd}+2$-exposed human proximal tubule cells. Toxicol Sci 2004, 80:358-366.

100. Nartey N, Cherian MG, Banerjee D: Immunohistochemical localization of metallothionein in human thyroid tumors. Am J Pathol 1987, 129:177-182.

101. Finn SP, Smyth P, Cahill S, Streck C, O'Regan EM, Flavin R, Sherlock J, Howells D, Henfrey R, Cullen M, Toner M, Timon C, O'Leary JJ, Sheils OM: Expression microarray analysis of papillary thyroid carcinoma and benign thyroid tissue: emphasis on the follicular variant and potential markers of malignancy. Virchows Arch 2007, 450:249-260.

102. Huang Y, Prasad M, Lemon WJ, Hampel H, Wright FA, Kornacker K, LiVolsi V, Frankel W, Kloos RT, Eng C, Pellegata NS, de la Chapelle A: Gene expression in papillary thyroid carcinoma reveals highly consistent profiles. Proc Nat Acad Sci USA 2001, 98:15044-15049.

103. Huang Y, de la Chapelle A, Pellegata NS: Hypermethylation, but not LOH, is associated with the low expression of MT1G and CRABP1 in papillary thyroid carcinoma. Int J Cancer 2003, 104:735-744.

104. Stephen JK, Chitale D, Narra V, Chen KM, Sawhney R, Worsham MJ: DNA methylation in thyroid tumorigenesis. Cancers (Basel) 2011, 3:1732-1743.

105. Venkataraman GM, Yatin M, Marcinek R, Ain KB: Restoration of iodide uptake in dedifferentiated thyroid carcinoma: relationship to human $\mathrm{Na}$ +/l-symporter gene methylation status. J Clin Endocrinol Metab 1999, 84:2449-2457

106. Fagin JA, Matsuo K, Karmakar A, Chen DL, Tang SH, Koeffler HP: High prevalence of mutations of the $\mathrm{p} 53$ gene in poorly differentiated human thyroid carcinomas. J Clin Invest 1993, 91:179-184.

107. Jones CJ, Shaw JJ, Wyllie FS, Gaillard N, Schlumberger M, Wynford-Thomas D: High frequency deletion of the tumour suppressor gene P16INK4a (MTS1) in human thyroid cancer cell lines. Mol Cell Endocrinol 1996, 116:115-119.

108. Durak I, Bayram F, Kavutcu M, Canbolat O, Ozturk HS: Impaired enzymatic antioxidant defense mechanism in cancerous human thyroid tissues. $J$ Endocrinol Invest 1996, 19:312-315.

109. Mano T, Shinohara R, Iwase K, Kotake M, Hamada M, Uchimuro K, Hayakawa N, Hayashi R, Nakai A, Ishizuki Y, Nagasaka A: Changes in free radical scavengers and lipid peroxide in thyroid glands of various thyroid disorders. Horm Metab Res 1997, 29:351-354.

110. Liu ZM, Hasselt CA, Song FZ, Vlantis AC, Cherian MG, Koropatnick J, Chen GG: Expression of functional metallothionein isoforms in papillary thyroid cancer. Mol Cell Endocrinol 2009, 302:92-98.

111. Liu ZM, Chen GG, Shum CK, Vlantis AC, Cherian MG, Koropatnick J, van Hasselt CA: Induction of functional MT1 and MT2 isoforms by calcium in anaplastic thyroid carcinoma cells. FEBS Lett 2007, 581:2465-2472.

112. Dumaz N, Marais R: Integrating signals between CAMP and the RAS/RAF/ MEK/ERK signalling pathways. Based on the anniversary prize of the Gesellschaft fur Biochemie und Molekularbiologie Lecture delivered on 5 July 2003 at the Special FEBS Meeting in Brussels. FEBS J 2005, 272:3491-3504.

doi:10.1186/1756-6614-5-26

Cite this article as: Pula et al: Role of metallothioneins in benign and malignant thyroid lesions. Thyroid Research 2012 5:26.

\section{Submit your next manuscript to BioMed Central and take full advantage of:}

- Convenient online submission

- Thorough peer review

- No space constraints or color figure charges

- Immediate publication on acceptance

- Inclusion in PubMed, CAS, Scopus and Google Scholar

- Research which is freely available for redistribution

Submit your manuscript at www.biomedcentral.com/submit
C Biomed Central 